\title{
Upaya Meningkatkan Kedisiplinan Siswa melalui Layanan Bimbingan Kelompok
}

\author{
Hilyati Fadhilah $^{1}$, Syahniar ${ }^{1}$, Megaiswari Biran Asnah ${ }^{1}$ \\ ${ }^{1}$ Universitas Negeri Padang
}

\author{
Article Info: \\ Accepted 19 Oktober 2019 \\ Published Online 30 Oktober 2019 \\ C IICET Journal Publication, 2019
}

\begin{abstract}
Discipline is one of the keys to a person's success, especially a student. If students are disciplined in learning, students will get good learning outcomes. Due to the development of the era in this global era, many students have begun to decrease their discipline in learning because many students have used smartphones, internet cafes and social gatherings. Therefore, it is hoped that through group guidance services can improve student learning discipline
\end{abstract}

Keyword: Student Discipline, Group Counseling, Guidance and Counseling

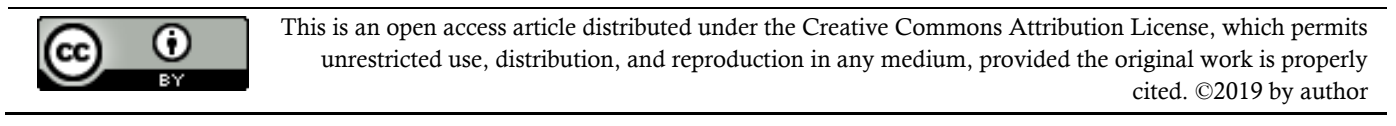

\section{PENDAHULUAN}

Kegiatan pendidikan pada dasarnya telah berjalan sejalan manusia itu ada. Upaya-upaya pendidikan dilakukan dalam rangka memberikan kemampuan kepada manusia untuk dapat hidup mandiri dan hidup bersama ditengah-tengah masyarakat, dewasa ini pendidikan mengalami banyak perbaikan demi terwujudnya cita-cita dan tujuan dari pendidikan itu sendiri.

Undang-undang nomor 20 tahun 2003 menjelaskan bahwa pendidikan nasional berfungsi mengembangkan kemampuan dan membentuk watak serta peradapan bangsa yang bermartabat dalam rangka mencerdaskan kehidupan bangsa, bertujuan untuk berkembangnya potensi peserta didik agar menjadi manusia yang beriman,bertaqwa kepada Tuhan Yang Maha Esa, berakhlak mulia, sehat, berilmu, cakap, kreatif, mandiri, dan menjadi warga negara yang demokratis serta bertanggung jawab. Dalam mencapai hasil belajar yang baik, ada beberapa faktor yang mempengaruhi baik dalam diri individu maupun dari luar diri individu. Sebagaimana yang dikemukakan Muhibbin Syah (2003:144) ada dua faktor yang mempengaruhi belajar, yang pertama faktor internal atau faktor dari dalam diri individu yang meliputi aspek fisikologis seperti intelegensi, motivasi dan kepribadian, yang kedua adalah faktor eksternal atau faktor dari luar diri individu yang meliputi lingkungan sosial dan lingkungan non sosial.

Dalam rangka mewujudkan tujuan pendidikan tersebut selain guru siswa juga berperan penting di dalamnya, jika siswa bisa menegakkan disiplin dengan baik maka pendidikan juga bisa berjalan dengan baik. Karena disiplin adalalah salah satu kunci kesuksesan.

\section{PEMBAHASAN \\ Pengertian disiplin belajar}

Kedisiplinan berasal dari kata disiplin yang berarti ta'at dan patuh terhadap suatu peraturan yang yang berlaku, dan mendapat imbuhan ke-dan-an jadi kedisiplinan bisa diartikan suatu sikap yang taat dan patuh terhadap suatu peraturan yang berlaku, tanpa suatu adanya peraturan maka tidak akan tercapailah suatu kedisiplinan, dengan adanya suatu peraturanakan melatih seseorang untuk disiplin dalam segala hal, dan dengan sikap yang selalu disiplin membuat seseorang berhasil dengan apa yang seseorang tersebut impikan itulah sebabnya kedisiplinan adalah modal utama suatu keberhasilan. 
Disiplin belajar siswa adalah suatu kunci yang dapat mewujudkan suasana belajar menjadi kondusif dan optimal. Idealnya siswa yang mengikuti pembelajaran di kel;as memiliki perhatiaan yang baik saaat belajar (Tu'lu 2004), dapat mematuhi tata tertib, menempatkan jadwal/ waktu (Arikunto, 1990) dapat berpartisipasi aktif, memiliki kesopanan, memiliki kehadiran yang baik di kelas (khaluase, 2009)

\section{Faktor-faktor yang mempengaruhi kedisiplinan belajar}

Menurut Elizabeth B. Hurlock (1999) faktor yang mempengaruhi kedisiplinan di antaranya :a.Sikap teman sebaya. Sikap teman sebaya merupakan salah satu faktor yang dapat mempengaruhi disiplin belajar sisw. Hubungan yang terjalin dengan baik dan sikap teman yang memberi arahan serta dukungan dan motivasi dalam kegiatan sekolah akan menujukkan sikap disiplin belajar bagi siswa tersebut.b.Sikap orang tuaSikap orang tua dapat mempengaruhi cara belajar anak. Perhatian orang tua merupakan salah satu komponen yang diperlukan dalam memndidik anak. Anak akan merasa terdorong untuk belajar karena orang tuanya selalu memberi dorongan atau motivasi untuk belajar dan mengawasi kegiatan belajarnya. Dengan adanya perhatian dan pengawasan orang tua maka siswa akan menunjukkan sikap disiplin belajar.c.Sikap guruHubungan yang terjadi antara guru dengan siswa akan berpengaruh terhadap disiplin belajar siswa. Siswa akan merasa senang bila guru brsikap baik terhadap dirinya. Siswa yang merasa diperhatikan dengan baik akan bersikap baik dengan guru. Dengan demikian siswa akan menunjukkan keadaan pada perintah guru dan melaksanaknan disiplin belajar sehingga dapat mencapai prestasi yang baik.d.Nilai Nilai-nilai yang menunjukkan keberhasilan atau kegagalan siswa dalam berbagai kegiatan akademis dapat mempengaruhi sikap siswa dalam belajar. Nilai-nilai akademis yang buruk dapat memacu siswa untuk belajar dengan disiplin agar mendapatkan nilai yang baik.Motivasi belajar"Motivasi adalah dorongan dasar yang menggerakkan seseorang bertingkah laku. Dorongan ini berada pada diri seseorang yang menggerakkan untuk melakukan sesuatu yang sesuai dengan dorongan dalam dirinya. Oleh karena itu, perbuatan seseorang yang didasarkan atas motivasi tertentu mengandung tema sesuai dengan motivasi yang mendasarinya" (Hamzah B.Uno, 2007)

\section{Disiplin siswa dalam menentukan dan menggunakan cara atau strategi belajar}

Keberhasilan siswa dalam studinya dipengaruhi oleh cara belajarnya. Siswa yang memiliki cara belajar yang efektip memungkinkan untuk mencapai hasil atau prestasi yang lebih tinggi dari pada siswa yang tidak mempunyai cara belajar yang efektip.

Untuk belajar secara efektip dan efisien diperlukan kesadaran dan disiplin tinggi setiap siswa. Belajar secara efektip dan efisien dapat dilakukan oleh siswa yang berdisiplin. Siswa yang memiliki disiplin dalam belajarnya akan berusaha mengatur dan menggunakan strategi dan cara belajar yang tepat baginya. Jadi langkah pertama yang perlu dimiliki agar dapat belajar secara efektip dan efisien adalah kesadaran atas tanggung jawab pribadi dan keyakinan bahwa belajar adalah untuk kepentingan diri sendiri, dilakukan sendiri dan tidak menggantungkan nasib pada orang lain.

Selain memiliki strategi belajar siswa yang tepat, siswa juga perlu memperhatikan metode atau cara yang harus dilakukan untuk mencapai tujuan dalam belajarnya. Seperti yang kita ketahui belajar bertujuan untuk mendapat pengetahuan, sikap, kecakapan dan keterampilan. Cara yang demikian itu jika dilakukan dengan penuh kesadaran dan disiplin tinggi maka akan menjadi suatu kebiasaan, dan kebiasaan dalam belajar berpengaruh terhadap prestasi belajar.

\section{Disiplin terhadap pemanfaatan waktu}

Salah satu masalah yang sering dihadapi oleh pelajar atau siswa adalah banyak pelajar atau siswa yang mengeluh kekuragan waktu untuk belajarnya, tetapi mereka sebenarnya kurang memiliki keteraturan dan disiplin untuk mempergunakan waktu secara efisien. Banyak waktu yang terbuangbuang disebabkan karna mengobrol omongan-omongan yang tidak habis-habisn. Sikap yang demikian itu harus ditinggalkan oleh siswa karena yang demikian itu tidak bermanfaat baginya.

Sebagaimana yang dikemukakan oleh The Liang Gie, 1995:167 mengemukakan bahwa keterampilan mengatur waktu merupakan suatu keterampilan yang sangat penting, bahkan ada ahli keterampilan studi yang berpendapat bahwa "keterampilan mengelola waktu dan menggunakan waktu secara efisien merupakan hal yang terpenting dalam masa studi maupun seluruh kehidupan siswa".

Banyak siswa yang belajarnya kurang dapat memanfaatkan waktunya dengan sebaik-baiknya karena tidak membagi-bagi waktunya untuk macam-macam keperluan, oleh karna itu, berbagai segi dan teknik untuk mengatur pemakaian waktu perlu dipahami sebagai langkah untuk mengembangkan keterampilan mengelola waktu studi. 
Setiap siswa perlu mengadakan prinsip belajar secara taratur.dan untuk belajar secara teratur setiap hari harus mempunyai rencana kerja. Agar siswa tidak bayak membuang waktu untuk memikirkan mata pelajaran yang akan dipekajari suatu saat dan apa yang harus dikerjakannya. Oleh karna itu agar siswa tidak dihinggapi keraguan-keraguan terhadap apa yang hendak dipelajarinya maka ia harus punya rencana kerja atau daftar waktu dalam belajar.

Adapun penjatahan waktu belajar siswa dapat dilakukan dengan membuat rencana belajar dalam bentuk jadwal belajar. Baik itu berupa jadwal belajar mingguan, harian, atuapun bulanan, dengan menentukan jumlah mata pelajaran yang akan dipelajarinya setiap hari serta menetapkan jadwalnya. Dimana setiap siswa dapat mengetahui sendiri pelajaran yang sulit ataupun mudah, sehingga dia dapat menentukan waktu yang sesuai atau cukup untuk mempelajarinya.

Sejalan sebagaimana yang dikatakan oleh Omar Hamalik,2005:31-32 agar rencana belajar yang baik mempunyai manfaat atau paedah. Adapun manfaat atau paedahnya antara lain (1) Menjadi pedoman danpenuntun dalam belajar, sehingga perbuatan belajar menjadi lebih teratur dan lebih sistematis, (2) Menjadi pendorong dalam belajar, (3) Menjadi alat bantu dalam belajar, (4) Rencana belajar yang baik akan membantu saudara untuk mengontrol, menilai, memeriksa sampai di mana tujuan saudara tercapai

Salah satu prinsip belajar adalah ulangan dan latihan. Sejalan dengan pendapat yang mengatakan bahwa : "Mengerjakan tugas dapat berupa pengerjaan tes atau ulangan atau ujian yang diberikan guru, tetapi juga termasuk membuat atau mengerjakan latihan-latihan yang ada dalam buku ataupun soal-soal buatan sendiri" Slameto, $2003: 87$

Berdasarkan pendapat tersebut di atas maka, tugas itu dapat berupa tes atau ulangan dan juga dapat berupa latihan-latihan soal atau pekerjaan rumah.jika siswa mempunyai kebiasaan untuk melatih diri mengerjakan soal-soal latihan serta mengerjakan pekerjaan rumah dengan disiplin, maka siswa tersebut tidak akan terlalu kesulitan dalam belajarnya, serta dapat dengan mudah mengerjakan setiap pekerjaan rumah yang diberikan oleh guru.

\section{Manfaat disiplin belajar}

Anak tumbuh menjadi pribadi yang peka/berperasaan halus dan percaya pada orang lain. Sikap ini memudahkan dirinya mengungkapkan perasaannya kepada orang lain, termasuk orang tuanya. Jadinya, anak akan mudah menyelami perasaan orang lain juga. Anak jadi peduli pada kebutuhan dan kepentingan orang lain.Disiplin membuat anak memiliki integritas, selain dapat memikul tanggung jawab, mampu memecahkan masalah dengan baik ,cepat dan mudah. Menurut penelitian menunjukkan bayi yang tenang/jarang menangis ternyata lebih mampu memperhatikan lingkungan sekitarnya dengan baik. Di tahap selanjutnya bahkan ia bisa cepat berinteraksi dengan orang lain. Sikap ini tumbuh berkembang pada saat anak diberi kepercayaan untuk melakukan sesuatu pekerjaan yang mampu ia kerjakan dengan sendiri. Dengan kemandirian anak dapat diandalkan untuk bisa memenuhi kebutuhan sendiri. Anak juga dapat mengeksplorasi lingkungan dengan baik.Disiplin merupakan bimbingan yang tepat pada anak untuk sanggup menentukan pilihan yang bijak. Anak menjadi cepat akrab dan ramah terhadap orang lain karena kemampuannya beradaptasi lebih terasah. Pada usia 3 tahun pertama, pertumbuhan otak anak sangat pesat, disini ia menjadi peniru perilaku yang piawai. ia mampu mencontoh dengan sempurna tingkah laku orang tua yang disiplin dengan sendirinya akan membentuk kebiasaan dan sikap yang positif.

\section{Layanan Bimbingan Kelompok}

Layanan bimbingan kelompok dikenal sebagai layanan primadona dalam kegiatan bimbingan dan konseling. Selain karena bisa mencakup sasaran layanan lebih banyak dalam pelaksanaan satu kali layanan, bimbingan kelompok juga dinilai efektif dalam membantu siswa mencapai tugas-tugas perkembangannya, karena selain peran individu lebih aktif juga memungkinkan terjadinya pertukaran pemikiran, pengalaman, perencanaan, dan penyelesaian masalah.Layanan bimbingan kelompok merupakan salah satu jenis layanan dalam bimbingan dan konseling Pola 17+, yang diberikan kepada siswa di sekolah, dan dapat membantu guru bimbingan dan konseling dalam upaya mengoptimalkan kemampuan individu agar dapat berkembang dengan baik.

Menurut Prayitno (1996:4) mengenai layanan bimbingan kelompok, yaitu :

Bimbingan Kelompok adalah suatu kegiatan yang dilakukan oleh sekelompok orang dengan memanfaatkan dinamika kelompok. Artinya, semua peserta dalam kegiatan kelompok saling berinteraksi, bebas mengeluarkan pendapat, menanggapi, member saran, dan lain-lain sebagainya; apa yang dibicarakan bermanfaat untuk diri peserta sendiri dan peserta lainnya.

Sedangkan Achmad Juntika (2006:23) mengemukakan bahwa bimbingan kelompok merupakan bantuan terhadap individu yang dilaksanakan dalam situasi kelompok.Bimbingan kelompok dapat berupa penyampaian informasi ataupun aktivitas kelompok membahas masalah- 
masalah pendidikan, pekerjaan, pribadi dan sosial.Bimbingan kelompok merupakan salah satu layanan dengan memanfaatkan dinamika kelompok, dalam kaitan ini Trotzer dalam Nandang Rusmaa (dalam sofwan Adiputra 2015 : 50) menjelaskan bahwa bimbingan kelompok merupakan suatu poses pemberian bantua kepada individu melalui suasana kelompok yag memungkinkan setiap anggota untuk belajar bepartisipasi aktif dan berbagai pengalaman dalam upaya pengembangan dalam upaya pengembangan wawasan, sikap, dan keterampilan yang diperlukan dalam upaya mencegah dan mengatasi masalah pribadi serta pemecahan masalahnya. Berdasarkan pada beberapa pengertian bimbingan kelompok di atas, maka dapat disimpulkan bahwa bimbingan kelompok merupakan salah satu jenis layanan Bimbingan dan Konseling yang di laksanakan dalam suasana kelompok dengan memanfaatkan dinamika kelompok guna memperoleh informasi dan pemahaman baru terkait topik yang menjadi bahasan.

Pemberian informasi dalam layanan bimbingan kelompok dimaksudkan untuk meningkatkan pemahaman tentang kenyataan, aturan-aturan dalam kehidupan, dan cara-cara yang dapat dilakukan untuk menyelesaikan tugas, serta meraih masa depan dalam studi, karier ataupun kehidupan. Lebih tepatnya lagi bahwa pelaksanaan layanan bimbingan kelompok memiliki tujuan untuk pengembangan diri.

\section{Kesimpulan}

Seiring dengan perkembangan zaman, gedjet, warnet setiap siswa bisa menggunakannya untuk hal positif sehingga tidak menurunkan disiplin belajar siswa. Sehingga siswa bisa mendapatkan hasil yang baik. Jadi salah satu yang bisa di gunakan yaitu layanan bimbingan kelompok.

\section{Daftar Rujukan}

Bella Puspita Sari. (2017). meningkatkan disiplin belajar siswamelalui manajemen kelas. http://ejournal.upi.edu.index.php/jpmanper/article/view/0000. Diakses 18 november 2019

Hamzah B. Uno. (2007). Teori Motivasi dan Pengukurannya: Analisis di Bidang Pendidikan. Jakarta: Bumi aksaraHurlock, B Elizabeth. (1999). Psikologi Perkembangan Anak Didik 2. Jakarta:Erlangga

Nurul Amalia, Zaini Rohmad, dan Slamet Subagya. Hubungan kedisiplinan belajar dan motivasi belajar dengan prestasi belajar sosiologi siswa kelas xi IPS MAN Purworejo. https://media.neliti.com/media/publications/165020-ID-hubungan-antara-kedisiplinanbelajar-dan.pdf. Diakses 18 November 2019

Oemar Hamalik. (2007). Proses Belajar Mengajar. Jakarta: Bumi Aksar

Prayitno. 1982. Pelaksanaan BK di Sekolah. Jakarta: Ghalia Indonesia.

Prayitno. 1995. Layanan Bimbingan dan Konseling Kelompok (Dasar dan Profil) Jakarta: Ghalia Indonesia.

Rasuna, L. 2009. Efektifitas Layanan Bimbingan Kelompok dalam meningkatkan Motivasi Belajar Siswa. Tesis tidak diterbitkan. Padang: Program Pascasarjana UNP Padang 